\title{
Selection component analysis of the Mpi locus in the amphipod Platorchestia platensis
}

\author{
John H. McDonald
}

Department of Ecology and Evolution, State University of New York at Stony Brook, Stony Brook, New York 11794, U.S.A.

Genotype frequencies of gravid females and their offspring, of non-gravid females, and of adult males were measured for the Mpi locus in a natural population of the amphipod Platorchestia platensis. These gave tests of gametic, sexual, fecundity and zygotic selection. The genotype distribution of adult males was significantly different from that of adult females. There were more heterozygous males than expected, suggesting that zygotic selection and not immigration produced the difference between the sexes.

\section{INTRODUCTION}

Few studies of enzyme loci have attempted to measure selection in natural populations. Fewer still have measured more than one component of selection; among the only loci for which gametic, fecundity, sexual, and zygotic selection have been measured in natural populations of animals are the loci coding for esterase in Zoarces viviparus (Christiansen et al., 1973, 1977), lactate dehydrogenase in Porcellio scaber (Sassaman, 1978), phosphoglucose isomerase in Sphaeroma rugicauda (Heath et al., 1988), and three loci in Peromyscus maniculatus (Nadeau and Baccus, 1981, 1983; Snyder, 1983). All components but fecundity have been measured for two loci in Gammarus oceanicus (Siegismund, 1985a). Such studies may help answer a number of questions about selection and enzyme loci: Could enzyme polymorphisms be maintained by simple one-locus overdominance, or are more elaborate models needed? How large are fitness differences among genotypes of enzyme loci? Is variation in fitness so large that selection resulting entirely from the enzyme locus itself is unlikely?

Like many other peracarid crustaceans, the amphipod Platorchestia platensis is a suitable species in which to measure components of selection. Females carry the eggs and newly hatched young in a brood pouch. Newly released young remain, like adults, nestled under wrack in the upper intertidal zone; there is no planktonic stage.
The main breeding season is in the spring. Although a few individuals which are born in the spring breed in the summer or early fall, most breed when they are a year old, then die by midsummer (Bock, 1967; Morino, 1978; Behbehani and Croker, 1982); thus generations are largely discrete and non-overlapping. The main breeding season on the north shore of Long Island lasts from early May to late June (J. H. McDonald, unpublished observations).

The Mpi locus in $P$. platensis codes for the enzyme mannose-6-phosphate isomerase (EC 5.3.1.8). The two alleles at this locus, $M \mathrm{Mi}^{90}$ and $M p i^{100}$, exhibit a consistent pattern of geographic differentiation, with $M p i^{90}$ more common on protected beaches than on exposed beaches (McDonald, 1987). The regularity of this pattern is evidence that it results from selection, although not necessarily that selection is ongoing in every population. Here I report evidence of zygotic selection within a single population.

\section{METHODS}

\section{Sample collection}

All samples were collected from a beach on the west side of Setauket Harbor, on the north shore of Long Island, New York. Amphipods were captured by hand from under the debris at the high tide line. On 2 May 1986 and 25 April 1987, females carrying eggs were collected for analysis of fecun- 
dity; each was put into an individual vial to prevent loss of eggs. The eggs were removed from the brood pouch and counted, and the females were lyophilized and weighed. On 6 and 8 May 1986 (the "early May 1986" sample) and 29 and 31 May, 1986 ("late May 1986"), females carrying newly hatched young or well-developed embryos were collected. These females could be distinguished in the field from those females with eggs and less-developed embryos, because eggs and early embryos are blue, while late embryos and hatched young are orange. These females were also kept in individual vials, and after removing and counting the young, four offspring from each female were saved for electrophoresis. Males large enough to be distinguished from females in the field were collected on 6 and 8 May 1986, and included in the early May 1986 sample. Males collected on 10 June 1986 were included in the late May 1986 sample. On 6 and 8 May 1987 ("early May 1987") and 15 and 16 June 1987 ("mid-June 1987"), all individuals except recently released young were collected, including gravid females, non-gravid females, and adult males. Because all of the hypothesis tests requiring offspring were far from significant in the 1986 samples, the tedious task of collecting large numbers of the few females carrying hatched young was not attempted in 1987.

\section{Electrophoresis}

Electrophoretic methods are given in McDonald (1987). Adult amphipods were lyophilized and weighed before electrophoresis; this had no effect on the allozyme patterns. All the individuals run were successfully scored. Females and their offspring were run on separate gels and scored independently, to avoid any bias against discordant results.

\section{Data analysis}

I sampled four offspring from each brood because I hoped to use the extended selection component analysis of Siegismund and Christiansen (1985), which requires at least three offspring per mother. This method depends on the assumption of single paternity of each brood; unfortunately, results from a multi-allelic peptidase locus indicated that some broods of $P$. platensis had more than one father (J.H. McDonald, unpublished data). Therefore I used the simple selection component analysis of Christiansen and Frydenberg (1973). Because this analysis does not assume single paternity of broods, it confounds male gametic and sexual selection in a single test and fails to detect certain patterns of non-random mating and male sexual selection. The sequence of hypotheses tested and the methods of testing used here follow Christiansen et al. $(1973,1977)$, with two modifications: (1) Estimates of transmitted male gamete frequencies were made using all four offspring of each female. The sample size of each gamete was divided by four for the statistical tests, as if only one male gamete per female had been sampled. In fact many broods contain both male gamete types; since in the initial analysis all of the tests involving male gametes were far from significance, the statistical contortions required to extract the maximum information about male gametes seemed unnecessary. (2) Instead of chi-square tests, $G$ tests of heterogeneity and goodness-of-fit were used throughout the analysis (Sokal and Rohlf, 1981). Where a component was analysed in more than one sample, the total $G$ value is the sum of the $G$ values from each sample.

\section{RESULTS}

The selection component analysis consists of a series of hypothesis tests, several of which depend on acceptance of the preceding null hypothesis. Christiansen and Frydenberg (1973) provide a detailed discussion of the methods, assumptions and limitations of each test. The data are shown in table 1 and the results of the analysis in table 2 .

\section{Female gametic selection}

In the absence of gametic selection in females, half the offspring of heterozygous females should be heterozygotes. This expectation is unaffected by multiple paternity, so all the offspring of heterozygous females were used. These was no evidence of gametic selection in females. Of 300 apparently homozygous females, none carried offspring with the other homozygous phenotype, so there was no evidence for null alleles in this population. This is in contrast to $\mathrm{Mpi}$ in G. oceanicus, where 4 of 223 homozygous females with offspring had discordant offspring, indicating a null allele with a frequency of 0.01 (Siegismund, 1985b).

\section{Random mating}

The paternal allele can be inferred for all offspring except heterozygous offspring of heterozygous females. Having accepted the hypothesis of no female gametic selection, the frequency of each 
Table 1 Mpi genotype counts in samples of $P$. platensis

\begin{tabular}{|c|c|c|c|c|c|c|c|}
\hline \multirow[b]{2}{*}{ Sample date } & \multirow{2}{*}{$\begin{array}{l}\text { Adult } \\
\text { genotype }\end{array}$} & \multicolumn{3}{|l|}{ Offspring } & \multirow{2}{*}{$\begin{array}{l}\text { Gravid } \\
\text { females }\end{array}$} & \multirow{2}{*}{$\begin{array}{l}\text { Non-gravid } \\
\text { females }\end{array}$} & \multirow[b]{2}{*}{ Males } \\
\hline & & $100 / 100$ & $100 / 90$ & $90 / 90$ & & & \\
\hline \multirow[t]{3}{*}{2 May 1986} & $100 / 100$ & - & -. & - & 26 & $\ldots$ & - \\
\hline & $100 / 90$ & -- & - & - & 58 & - & - \\
\hline & $90 / 90$ & - & - & - & 21 & - & - \\
\hline \multirow{3}{*}{ Early May 1986} & $100 / 100$ & 225 & 199 & 0 & 106 & - & 98 \\
\hline & $100 / 90$ & 157 & 287 & 136 & 145 & - & 172 \\
\hline & $90 / 90$ & 0 & 123 & 109 & 58 & - & 52 \\
\hline \multirow[t]{3}{*}{ Late May 1986} & $100 / 100$ & 186 & 130 & 0 & 79 & - & 53 \\
\hline & $100 / 90$ & 175 & 323 & 138 & 159 & - & 105 \\
\hline & $90 / 90$ & 0 & 131 & 97 & 57 & - & 39 \\
\hline \multirow[t]{3}{*}{25 April 1987} & $100 / 100$ & - & - & - & 86 & - & - \\
\hline & $100 / 90$ & - & - & - & 139 & - & - \\
\hline & $90 / 90$ & - & - & - & 57 & - & - \\
\hline \multirow[t]{3}{*}{ Early May 1987} & $100 / 100$ & - & - & _- & 317 & 191 & 378 \\
\hline & $100 / 90$ & - & - & - & 492 & 337 & 656 \\
\hline & $90 / 90$ & - & - & - & 242 & 149 & 256 \\
\hline \multirow{3}{*}{ Mid-June 1987} & $100 / 100$ & - & - & - & 128 & 69 & 147 \\
\hline & $100 / 90$ & - & - & - & 239 & 146 & 271 \\
\hline & $90 / 90$ & - & - & - & 120 & 57 & 95 \\
\hline
\end{tabular}

mother-offspring combination was used to estimate paternal allele frequencies. There was no evidence of non-random mating. The heterogeneity in inferred paternal allele frequency among female genotypes appears smaller than would be expected by chance alone; this is because the test conservatively assumes only one offspring per female, when in fact the data consist of four offspring per female.

\section{Female sexual selection}

In 1986 only gravid females were collected, and therefore female sexual selection could not be

Table 2 Results of the selection component analysis

\begin{tabular}{|c|c|c|c|c|}
\hline Null hypothesis & Sample & $G$ & $\mathrm{df}$ & $P$ \\
\hline No female gametic selection & $\begin{array}{l}\text { Early May } 1986 \\
\text { Late May } 1986 \\
\text { Total } 1986\end{array}$ & $\begin{array}{l}0 \cdot 06 \\
0 \cdot 16 \\
0 \cdot 22\end{array}$ & $\begin{array}{l}1 \\
1 \\
2\end{array}$ & $\begin{array}{l}0.80 \\
0.69 \\
0.90\end{array}$ \\
\hline Random mating & $\begin{array}{l}\text { Early May } 1986 \\
\text { Late May } 1986 \\
\text { Total } 1986\end{array}$ & $\begin{array}{l}0 \cdot 01 \\
0 \cdot 14 \\
0 \cdot 15\end{array}$ & $\begin{array}{l}2 \\
2 \\
4\end{array}$ & $\begin{array}{l}1 \cdot 0 \\
0 \cdot 93 \\
1 \cdot 0\end{array}$ \\
\hline No female sexual selection & $\begin{array}{l}\text { Early May } 1987 \\
\text { Mid-June } 1987 \\
\text { Total } 1987\end{array}$ & $\begin{array}{l}1 \cdot 48 \\
1 \cdot 81 \\
3 \cdot 29\end{array}$ & $\begin{array}{l}2 \\
2 \\
4\end{array}$ & $\begin{array}{l}0 \cdot 48 \\
0 \cdot 40 \\
0 \cdot 51\end{array}$ \\
\hline No adult viability selection in females & $\begin{array}{l}1986 \\
1987 \\
\text { Total }\end{array}$ & $\begin{array}{r}5 \cdot 83 \\
4 \cdot 38 \\
10 \cdot 20\end{array}$ & $\begin{array}{l}4 \\
4 \\
8\end{array}$ & $\begin{array}{l}0 \cdot 21 \\
0 \cdot 36 \\
0 \cdot 25\end{array}$ \\
\hline No adult viability selection in males & $\begin{array}{l}1986 \\
1987 \\
\text { Total }\end{array}$ & $\begin{array}{l}1 \cdot 44 \\
0 \cdot 66 \\
2 \cdot 11\end{array}$ & $\begin{array}{l}2 \\
2 \\
4\end{array}$ & $\begin{array}{l}0 \cdot 49 \\
0 \cdot 72 \\
0 \cdot 72\end{array}$ \\
\hline $\begin{array}{l}\text { Equality of cohorts in females } \\
\text { Equality of cohorts in males }\end{array}$ & $\begin{array}{l}\text { Total } \\
\text { Total }\end{array}$ & $\begin{array}{l}3 \cdot 88 \\
1 \cdot 10\end{array}$ & $\begin{array}{l}2 \\
2\end{array}$ & $\begin{array}{l}0 \cdot 14 \\
0 \cdot 58\end{array}$ \\
\hline $\begin{array}{l}\text { Equality of male gametes among samples } \\
\text { No male gametic or sexual selection }\end{array}$ & $\begin{array}{l}1986 \\
\text { Total }\end{array}$ & $\begin{array}{l}0 \cdot 80 \\
0 \cdot 01\end{array}$ & $\begin{array}{l}1 \\
1\end{array}$ & $\begin{array}{l}0 \cdot 37 \\
0 \cdot 94\end{array}$ \\
\hline Equality of zygotic selection in sexes & Total & $7 \cdot 31$ & 2 & $0 \cdot 03$ \\
\hline
\end{tabular}


tested. The early May 1987 and mid-June 1987 samples included all adult females, so that genotypes of females with eggs or young could be compared with genotypes of non-gravid females. Because females breed at different times during the breeding season, this is not a complete test of sexual selection, as the non-gravid females include those which have not yet bred and those which have already bred and have released their young, along with any genuinely non-breeding females. There was no significant difference in genotype distribution between gravid and non-gravid females, and thus no evidence of female sexual selection. Gravid and non-gravid females were therefore pooled for the remaining tests.

\section{Fecundity}

The effect of genotype on fecundity was analyzed using an analysis of covariance, with dry weight of the female as the covariate (table 3 ). This tests only the number of offspring per brood; a true measure of lifetime fecundity also needs information on the number of broods each female produced. There was no significant difference in weight-specific fecundity among genotypes in any of the four samples. Weight-specific fecundity was about 14 per cent lower for females carrying embryos or young (early May 1986 and late May 1986) than for females carrying eggs ( 2 May 1986 and 25 April 1987). This difference represents either death of embryos or release of young before capture.

\section{Adult viability}

In both 1986 and 1987, one sample of males and two of females were collected early in the breeding season, and one sample of each sex was collected later. A difference in genotype distribution between samples from different times in the breeding season would indicate either viability selection operating on adults or migration from a genetically different population. Because differences between the sexes had not yet been tested, the samples from different times were compared separately for each sex. There were no significant differences among samples in either sex, so with no evidence for adult viability selection all the samples from each year were pooled for the remaining tests.

\section{Temporal stability of the population}

A central assumption of the selection component analysis is that the population is at equilibrium. This was tested by comparing the 1986 and 1987 adult cohorts. A temporal difference in genotype distribution would indicate either a directional trend or a difference in the way selection affected each cohort. There was no significant difference in genotype frequency between the 1986 and 1987 adults in either sex, so samples from the two years were pooled for the remaining tests.

\section{Male gametic and sexual selection}

Because of the multiple paternity of broods, only allele frequencies of male parents, not genotype frequencies, can be estimated. Therefore patterns of over- or underdominant selection which did not change allele frequencies would not be detected. In addition, male gametic and sexual selection are confounded into a single test of the hypothesis that the allele frequencies in the transmitted male gametes are the same as those in the adult males. The inferred male gamete frequencies in the two 1986 offspring samples were first compared; they were not significantly different and were pooled. The pooled sample of male gametes was then compared to the total adult male sample. They were not significantly different.

\section{Juvenile zygotic selection}

The first test involving this component compared the genotype distributions of adult males and females, to determine whether juvenile zygotic selection-differences in viability occurring before adulthood-had the same effect on each sex. The genotype frequencies of the two sexes were sig-

Table 3 Results of analysis of covariance of fecundity

\begin{tabular}{|c|c|c|c|c|c|c|}
\hline \multirow[b]{2}{*}{ Sample } & \multicolumn{3}{|c|}{ Weight-adjusted fecundity } & \multirow[b]{2}{*}{$N$} & \multirow[b]{2}{*}{$F$} & \multirow[b]{2}{*}{$P$} \\
\hline & $100 / 100$ & $100 / 90$ & $90 / 90$ & & & \\
\hline 2 May 1986 & $21 \cdot 2$ & $21 \cdot 7$ & $20 \cdot 1$ & 105 & 0.78 & $0 \cdot 46$ \\
\hline Early May 1986 & $19 \cdot 8$ & $20 \cdot 9$ & $20 \cdot 6$ & 340 & $1 \cdot 53$ & $0 \cdot 22$ \\
\hline Late May 1986 & $23 \cdot 6$ & 23.9 & $22 \cdot 4$ & 198 & 0.82 & 0.44 \\
\hline 25 April 1987 & $22 \cdot 2$ & $22 \cdot 3$ & $22 \cdot 2$ & 282 & 0.01 & 0.99 \\
\hline
\end{tabular}


Table 4 Genotype frequencies

\begin{tabular}{|c|c|c|c|c|c|}
\hline & & \multicolumn{3}{|l|}{ Genotype } & \multirow[b]{2}{*}{$N$} \\
\hline & & $100 / 100$ & $100 / 90$ & $90 / 90$ & \\
\hline Expected zygotes & & $0 \cdot 294$ & 0.496 & $0 \cdot 209$ & - \\
\hline Females & $\begin{array}{l}2 \text { May } 1986 \\
\text { Early May } 1986 \\
\text { Late May } 1986 \\
25 \text { April } 1987 \\
\text { Early May } 1987 \\
\text { Mid-June } 1987 \\
\text { Total }\end{array}$ & $\begin{array}{l}0 \cdot 248 \\
0 \cdot 343 \\
0 \cdot 268 \\
0 \cdot 305 \\
0 \cdot 294 \\
0 \cdot 260 \\
0 \cdot 288\end{array}$ & $\begin{array}{l}0.552 \\
0.469 \\
0.539 \\
0.493 \\
0.480 \\
0.507 \\
0.493\end{array}$ & $\begin{array}{l}0 \cdot 200 \\
0 \cdot 188 \\
0 \cdot 193 \\
0 \cdot 202 \\
0 \cdot 226 \\
0 \cdot 233 \\
0 \cdot 219\end{array}$ & $\begin{array}{r}105 \\
309 \\
295 \\
282 \\
1728 \\
759 \\
3478\end{array}$ \\
\hline Males & $\begin{array}{l}\text { Early May } 1986 \\
\text { Late May } 1986 \\
\text { Early May } 1987 \\
\text { Mid-June } 1987 \\
\text { Total }\end{array}$ & $\begin{array}{l}0 \cdot 304 \\
0 \cdot 269 \\
0 \cdot 293 \\
0 \cdot 287 \\
0 \cdot 291\end{array}$ & $\begin{array}{l}0.534 \\
0.533 \\
0.509 \\
0.528 \\
0.519\end{array}$ & $\begin{array}{l}0 \cdot 161 \\
0 \cdot 198 \\
0 \cdot 198 \\
0 \cdot 185 \\
0 \cdot 190\end{array}$ & $\begin{array}{r}322 \\
197 \\
1290 \\
513 \\
2322\end{array}$ \\
\hline
\end{tabular}

nificantly different, largely because of a greater frequency of heterozygotes and a smaller frequency of $M p i^{90 / 90}$ homozygotes in males compared with females (table 4).

If the preceding null hypothesis, that zygotic selection affected the sexes equally, had been accepted, the next step would have been to pool the sexes and test for juvenile zygotic selection by comparing the observed genotype distribution in adults with the zygotic distribution expected under Hardy-Weinberg assumptions. However, since there is a significant difference in genotype distribution between the sexes, the sexes cannot be pooled. Instead the expected distribution is calculated by taking into account the difference in allele frequency between the sexes, yielding a slightly higher frequency of heterozygotes than the usual Hardy-Weinberg proportions. The genotypic distribution of each sex can be compared to this expected zygotic distribution; the difference was barely significant for males $(G=6.37, P=0.04$, $2 \mathrm{df}$ ) but not for females ( $G=2 \cdot 07, P=0 \cdot 36,2 \mathrm{df}$ ). These tests are not, however, independent of the test of the difference between the sexes: a difference in allele frequencies between the sexes would cause the genotype distributions of the sexes to differ from each other, and it would also cause the distribution of each sex to differ from the expected distribution derived from both sexes. The comparison of each sex with the expected zygotic distribution may provide information about the magnitude and nature of selection, but the selection component analysis must stop with the rejection of the hypothesis that juvenile zygotic selection affects the sexes equally.

\section{DISCUSSION}

Adult male $P$. platensis differed significantly in genotype distribution from adult females. Before accepting zygotic selection as the cause of this pattern, several other possibilities must be considered.

(a) Scoring errors. When dealing with such small deviations from expectations, a few systematic scoring errors could cause a serious problem. $M p i$ in $P$. platensis produces one or two clear, well-separated bands of equal staining intensity, with no evidence of "ghost" bands. Very few individuals needed to be repeated due to faintness or gel defects, and all individuals were scored for Mpi. It is also difficult to imagine how scoring errors could differ between the sexes.

(b) Cryptic species. The only other amphipod which is found in the same habitat, Orchestia grillus, has MPI allozymes which have much slower mobility than those of $P$. platensis.

(c) Size-biased sampling. The 1986 samples of males contained only males large enough to be sexed in the field. In 1987 I attempted to catch all amphipods seen, but there may have been an unconscious bias towards the more conspicuous and slower moving large individuals. Any difference in size between genotypes might therefore cause apparent differences in genotype frequencies. All the adults were lyophilized and weighed; analysis of variance of log-transformed dry weights did not reveal significant heterogeneity in dry weight among genotypes for any sample of either sex, so size-related artifacts do not seem to be a problem. 
(d) Immigration. The Mpi locus exhibits a repeated pattern of geographic differentiation, with the $M p i^{90}$ allele more common on protected than on exposed beaches (McDonald, 1987). The Setauket Harbor site sampled here is intermediate, both geographically and in allele frequency, between the exposed and protected beaches in the area. If the sexes differed in the amount of immigration from a beach with a different allele frequency, a difference in genotype distributions could result. However, such population mixing would produce a slight deficit of heterozygotes; since males had an excess of heterozygotes over expected proportions, population mixing seems unlikely to be the sole cause of the observed pattern.

Having eliminated such causes, a difference in juvenile zygotic selection between the sexes seems the most likely explanation, and gives one of the few examples of a sex-related difference in viability selection at an autosomal enzyme locus. The importance of treating the sexes separately in studies of selection can be appreciated by considering the consequences of failing to distinguish males and females in this study. There would have been a slight excess of heterozygotes compared with Hardy-Weinberg expectations $\left(F_{I S}=-0.013\right)$, but it would have been quite non-significant ( $G=$ $1 \cdot 03, P=0 \cdot 31,1 \mathrm{df})$.

The fitness of each $M p i$ genotype relative to the heterozygote was estimated for adult males, adult females, and combined adults (with both sexes weighted equally). These fitness estimates (table 5) should be used with caution. The genotype distribution was significantly different from expected zygotic proportions only in adult males, and that test was not statistically independent of the earlier test of the difference between the sexes. Because tests of some components in a selection component analysis are quite weak (Christiansen and Frydenberg, 1973), large differences in other components of fitness easily could have been undetected. For comparison, relative fitnesses were also calculated for several other studies which have demonstrated selection at enzyme loci in natural populations of animals (table 5). In each case, the fitnesses relative to the genotype with the greatest fitness are listed. These are all partial fitnesses involving a single selection component, not overall net fitnesses.

One question which can be examined is whether simple overdominance might maintain the polymorphism. At five of the eight loci listed (including the non-significant result for total zygotic selection of $M p i$ in $P$. platensis), the heterozygote had the greatest fitness. This is sufficient to maintain a two-allele polymorphism. The homozygote of the rarer allele had higher fitness for two components of selection of Pgi in $S$. rugicauda; however, gametic selection favoured the common allele in a way that could yield a balanced polymorphism (Heath et al., 1988). The common homozygote had higher fecundity than heterozygotes for Pgi in Asellus aquaticus (Shihab and Heath, 1987a); seasonal changes in genotype frequencies, and field cage experiments, indicate

Table 5 Relative fitnesses of genotypes at allozyme loci

\begin{tabular}{|c|c|c|c|c|c|c|}
\hline \multirow[b]{2}{*}{ Species } & \multirow[b]{2}{*}{ Locus } & \multirow[b]{2}{*}{ Component } & \multicolumn{3}{|c|}{ Fitness } & \multirow[b]{2}{*}{ Reference } \\
\hline & & & $a a$ & $a b$ & $b b$ & \\
\hline Platorchestia platensis & Mpi & Zygotic in males & 0.95 & 1 & 0.87 & 1 \\
\hline Platorchestia platensis & $M p i$ & Zygotic in females & 0.94 & 0.95 & 1 & 1 \\
\hline Platorchestia platensis & $M p i$ & Total zygotic & 0.97 & 1 & 0.96 & 1 \\
\hline Asellus aquaticus & Pgi & Fecundity & 1 & 0.63 & - & 2 \\
\hline Colias eurytheme & $\mathrm{Pgi}$ & Male sexual & $0 \cdot 33$ & 1 & - & 3 \\
\hline Colias eurytheme & $G 6 p d$ & Male sexilal & $0 \cdot 23$ & 1 & - & 4 \\
\hline Colias eurytheme & $P g m$ & Male sexual & 0.45 & 1 & - & 4 \\
\hline Peromyscus maniculatus & $A d h$ & Female sexual & 0.53 & 1 & $0 \cdot 42$ & 5 \\
\hline Porcellio scaber & $L d h$ & Zygotic & $0 \cdot 88$ & 1 & 0.64 & 6 \\
\hline Sphaeroma rugicauda & $P g i$ & Zygotic & 0.71 & 0.43 & 1 & 7 \\
\hline Sphaeroma rugicauda & Pgi & Fecundity & 0.81 & 0.85 & 1 & 8 \\
\hline Zoarces viviparus & Est & Zygotic & 0.97 & 0.94 & 1 & 9 \\
\hline
\end{tabular}

$a a$ : most common homozygote; $a b$ : most common heterozygote; $b b$ : second most common homozygote. All homozygotes and all heterozygotes were pooled for Colias eurytheme. Mean fitnesses were calculated over six samples for Porcellio scaber. Juvenile zygotic selection in Sphaeroma rugicauda was calculated from the difference in genotype distribution between samples from Augisst (newly released young) and June (adults). References: (1) This study; (2) Shihab and Heath, 1987a; (3) Watt et al., 1985; (4) Carter and Watt, 1988; (5) Nadeau and Baccus, 1981; (6) Sassaman, 1978; (7) Edwards and Heath, 1983a; (8) Edwards and Heath, 1983b; (9) Christiansen et al., 1977. 
that zygotic selection may favour heterozygotes at some times of the year (Shihab and Heath, 1987b). Heterozygotes appeared to have the lowest zygotic fitness at the Est locus in the fish $Z$. viviparus, and extensive studies have not revealed a counteracting selection component that would result in a balanced polymorphism (Christiansen et al., 1973, 1977); one possibility is that heterozygotes swim slightly faster and were better able to escape being caught in the nets.

When selection is detected in natural populations, it is unknown whether the differences in fitness result entirely from the locus examined or whether other loci in gametic disequilibrium also contribute. Since only a few independent loci could simultaneously exhibit large variation in fitness, an observation of such large variation suggests that a group of loci in gametic disequilibrium may be responsible. For example, a male heterozygous for the Pgi locus in Colias eurytheme is three times as likely to mate as a homozygote, and a male heterozygous for G6pd has over four times the mating success of a homozygote (table 5 ). In contrast, the fairly small differences in fitness among $M p i$ genotypes in $P$. platensis leave open the possibility that selection may result entirely from the Mpi locus itself.

Acknowledgements I thank J. W. Ajioka, K. W. Dunn, W. F. Eanes, R. K. Koehn, M. K. Krause, and P. J. N. Silva for many helpful comments on earlier versions of the manuscript. This is contribution number 701 in Ecology and Evolution at the State University of New York, Stony Brook.

\section{REFERENCES}

BEHBEHANI, M. I. AND CROKER, R. A. 1982. Ecology of beach wrack in northern New England with special reference to Orchestia platensis. Estuar. Coast. Shelf Sci., 15, 611-620.

BOCK, K.-D. 1967. Experimente zur Ökologie von Orchestia platensis Kroyer. Z. Morph. Ökol. Tiere, 58, 405-428.

CARTER, P. A. AND WATT, W. B. 1988. Adaptation at specific loci. V. Metabolically adjacent enzyme loci may have very distinct experiences of selective pressures. Genetics, 119, 913-924.

CHRISTIANSEN, F. B. AND FRYDENBERG, O. 1973. Selection component analysis of natural polymorphisms using population samples including mother-offspring combinations. Theor. Popul. Biol., 4, 425-445.

CHRISTIANSEN, F. B., FRYDENBERG, O. AND SIMONSEN, V. 1973. Genetics of Zoarces populations. IV. Selection component analysis of an esterase polymorphism using population samples including mother-offspring combinations. Hereditas, 73, 291-304.
CHRISTIANSEN, F. B., FRYDENBERG, O. AND SIMONSEN, V. 1977. Genetics of Zoarces populations. X. Selection component analysis of the EstIII polymorphism using samples of successive cohorts. Hereditas, 87, 129-150.

EDWARDS, J. P. AND HEATH, D. J. 1983 a. Dynamics of an enzyme polymorphism in the isopod, Sphaeroma rugicauda (Leach). I. Temporal variation in genotype frequencies. Heredity, 51, 467-475.

EDWARDS, J. P. AND HEATH, D. J. $1983 b$. Dynamics of an enzyme polymorphism in the isopod, Sphaeroma rugicauda (Leach). II. Sexual, gametic and fecundity selection. Heredity, 51, 477-486.

HEATH, D. J., RIDDOCH, B. J., CHILDS, D. AND RATFORD, J. R. 1988. Selection component analysis of the PGI polymorphism in Sphaeroma rugicauda. Heredity, 60, 229-235.

MCDONALD, J. H. 1987. Repeated geographic variation at three enzyme loci in the amphipod Platorchestia platensis. Evolution, 41, 438-441.

MORINO, H. 1978. Studies on the Talitridae (Amphipoda, Crustacea) in Japan. III. Life history and breeding activity of Orchestia platensis Kroyer. Publ. Seto Mar. Biol. Lab., 24, 245-267.

NADEAU, J. H. AND BACCUS, R. 1981. Selection components of four allozymes in natural populations of Peromyscus maniculatus. Evolutions, 35, 11-23.

NADEAU, J. H. AND BACCUS, R. 1983. Gametic selection and hemoglobin polymorphisms in Peromyscus maniculatus: a rejoinder. Evolution, 37, 642-646.

SASSAMAN, C. 1978. Dynamics of a lactate dehydrogenase polymorphism in the wood louse Porcellio scaber Latr.: evidence for partial assortative mating and heterosis in natural populations. Genetics, 88, 591-609.

SHIHAB, A. F. AND HEATH, D. J. 1987 a. Components of fitness and the PGI polymorphism in the freshwater isopod Asellus aquaticus (L). 1. Fecundity selection. Heredity, 58, 69-73.

SHIHAB, A. F. AND HEATH, D. J. 1987 b. Components of fitness and the PGI polymorphism in the freshwater isopod Asellus aquaticus (L.) 2. Zygotic selection Heredity, 58, 289-295.

SIEGISMUND, H. R. 1985 a. Genetic studies of Gammarus. IV. Selection component analysis of the Gpi and Mpi loci in Gammarus oceanicus. Hereditas, 102, 241-250.

SIEGISMUND, H. R. $1985 \mathrm{~b}$. Genetic studies of Gammarus. III. Inheritance of electrophoretic variants of the enzymes mannose phosphate isomerase and glucose phosphate isomerase in Gammarus oceanicus. Hereditas, 102, 25-31.

SIEGISMUND, H. R. AND CHRISTIANSEN, F. B. 1985. Selection component analysis of natural polymorphisms using population samples including mother-offspring combinations, III. Theor. Popul. Biol., 27, 268-297.

SNYDER, L. R. G. 1983. Selection components affecting hemoglobins in Peromyscus maniculatus: a re-evaluation. Evolution, 37, 639-642.

SOKAL, R. R. AND ROHLF, F. J. 1981 Biometry. W. H. Freeman, San Francisco.

WATT, W., CARTER, P. A. AND BLOWER, S. M. 1985. Adaptation at specific loci. IV. Differential mating success among glycolytic allozyme genotypes of Colias butterfies. Genetics, $109,157-175$. 